\title{
ANALISIS PENGARUH GAYA KEPEMIMPINAN DAN INSENTIF TERHADAP KINERJA KARYAWAN PADA YAYASAN PENDIDIKAN MULIA BUANA
}

Aden Prawiro Sudarso. S.E., M. M. Dosen Fakultas Ekonomi Universitas Pamulang

Email :aden.prawiro@gmail.com

\begin{abstract}
ABSTRAK
Penelitian ini bertujuan untuk mengetahui pengaruh gaya kepemimpinan dan insentif terhadap kinerja karyawan baik secara parsial dan simultan dengan menggunakan metode penelitian deskriftif kuantitatif. Responden dalam penelitian ini adalah karyawan Yayasan Pendidikan Mulia Buana Parungpanjang yang berjumlah 87 responden.

Hasil penelitian ini dapat disimpulkan sebagai berikut: (1) Terdapat pengaruh yang positif dan signifikan antara gaya kepemimpinan dengan kinerja karyawan dengan nilai $t_{\text {hitung }} 3,366>t_{\text {tabel }} 1,667$. Nilai koefisien regresi parsial sebesar 0,336 atau 33,6\% dan nilai signifikansi 0,001 , hal ini berarti lebih besar dari taraf kepercayaan yang telah ditetapkan sebesar $0,05(5 \%)$. (2) Terdapat pengaruh yang positif dan signifikan antara insentif dengan kinerja karyawan dengan nilai $t_{\text {hitung }} 3,621>t_{\text {tabel }} 1,667$. Nilai koefisien regresi parsial sebesar 0,318 atau 31,8\% dan nilai signifikansi 0,001, hal ini berarti lebih besar dari taraf kepercayaan yang telah ditetapkan sebesar 0,05 (5\%). (3) Terdapat pengaruh yang positif dan signifikan antara gaya kepemimpinan dan insentif dengan kinerja karyawan dengan nilai $F_{\text {hitung }} 15,072>F_{\text {tabel }} 3,11$. Nilai koefisien regresi secara simultan sebesar 0,264 atau 26,4\% sedangkan sisanya sebesar 73,6\% dijelaskan oleh variabel lain diluar variabel penelitian ini.
\end{abstract}

\section{Kata Kunci : Gaya Kepemimpinan, Insentif dan Kinerja Karyawan}




\section{PENDAHULUAN}

\section{A. Latar Belakang Masalah}

Setiap institusi atau organisasi, baik organisasi profit maupun non profit mengharapkan dukungan bahkan sangat tergantung pada sumberdaya yang terampil, ahli, profesional dan berprestasi. Dalam suatu organisasi fungsi dan peran seorang pemimpin dalam mendorong pembentukan organisasi yang diharapkan mampu optimal agar proses manajemen dalam organisasi dapat berjalan efektif. Insentif mampu memberikan motivasi yang efektif terhadap karyawan, dengan adanya insentif yang baik, adil dan layak diharapkan para karyawan mampu bekerja sesuai dengan kompetensi secara optimal.

Yayasan Pendidikan Mulia Buana adalah Lembaga sosial yang bergerak dibidang pendidikan formal yakni Sekolah Menengah Atas (SMA) dan Sekolah Menengah Kejuruan (SMK). Saat ini lembaga beralamat di Jalan Pesantren no. 23 Desa Kabasiran Kecamatan Parungpanjang Kabupaten Bogor. Dalam mengembangkan organisasi dua lembaga sekolah tersebut bekerja dengan satu manajemen yayasan. Yayasan Pendidikan Mulia Buana mempunyai visi yang diembannya yaitu "Menjadikan Yayasan Pendidikan Mulia Buana Sebagai Pondasi Lembaga pendidikan yang unggul, terdepan dan berprestasi".

MSDM sangat diperlukan oleh setiap organisasi-organisasi. "ketercapaian kinerja produktif perlu ditunjang oleh kepemimpinan yang mampu membawa bawahannya menyatukan tujuan organisasi, insentif yang dapat memenuhi kebutuhan hidup layak, jaminan sosial yang memadai kondisi kerja yang manusiawi dan hubungan kerja yang harmonis".Melihat hal hal tersebut diatas perluadanya perhatian khusus organisasi pada Gaya Kepemimpinan, Insentif dan Kinerja Karyawan pada Yayasan Pendidikan Mulia Buana (YPMB) Parungpanjang Bogor.

\section{B. Pembatasan Masalah}

Dalam penulisan ini penulis membatasi hanya mencakup tentang

1. Peran kepemimpinan dalam memimpin bawahannya

2. Seluruh karyawan dapat menerima insentif agar bekerja dengan baik

3. Seluruh karyawan dapat meningkatkan kinerja agar semakin lebih baik

\section{Perumusan Masalah}

Secara operasional masalah pokok dalam penelitian ini dapat dirumuskan sebagai berikut:

1. Apakah gaya kepemimpinan berpengaruh signifikan terhadap kinerja karyawan?

2. Apakah insentif berpengaruh signifikan terhadap kinerja karyawan?

3. Apakah gaya kepemimpinan dan insentif secara simultan berpengaruh signifikan terhadap kinerja karyawan?

\section{Tujuan Penelitian}

$\begin{array}{lr}\text { 1. Untuk } & \text { mengetahui } \\ \text { pengaruh } & \text { gaya } \\ \text { kepemimpinan } & \text { terhadap } \\ \text { kinerja karyawan. } & \end{array}$


2. Untuk mengetahui pengaruh insentif terhadap kinerja karyawan.

3. Untuk mengetahui pengaruh gaya kepemimpinan dan insentif terhadap kinerja karyawan secara simultan.

\section{TINJAUAN PUSTAKA DAN KERANGKA PEMIKIRAN}

\section{A. Tinjauan Pustaka}

\section{Manajemen Sumber Daya Manusia (MSDM)}

Manajemen sumberdaya manusia menurut Malayu S.P Hasibuan (2004:10) yang menyatakan bahwa "Manajemen sumberdaya manusia adalah ilmu dan seni mengatur hubungan dan peranan tenaga kerja agar efektif dan efisien membantu terwujudnya tujuan perusahaan, karyawan dan masyarakat". Adapun Manajemen sumber daya manusia menurut Veithzal Riva'i (2009:1) merupakan salah satu bidang dari manajemen umum yang meliputis segi-segi perencanaan, pengorganisasian, pelaksanaan dan pengendalian. Proses ini terdapat dalam fungsi/bidang produksi, pemasaran, keuangan maupun kepegawaian.

\section{Gaya Kepemimpinan}

Menurut Veitzal Riva'i (2005:2), definisi kepemimpinan secara luas, adalah meliputi proses mempengaruhi dalam menentukan tujuan organisasi, memotivasi perilaku pengikut untuk mencapai tujuan, mempengaruhi interprestasi mengenai peristiwa-peristiwa para pengikutnya, pengorganisasian dan aktivitas-aktivitas untuk mencapai sasaran, memelihara hubungan kerja sama dan kerja kelompok, perolehan dukungan dan kerja sama dari orang-orang di luar kelompok atau organisasi. Menurut rivai ada tiga macam gaya kepemimpinan yaitu gaya kepemimpinan otoriter, demokratis dan kendali bebas.

\section{Insentif}

Menurut Veitzhal Rivai (2009:767), mengemukakan bahwa insentif adalah bentuk pembayaran yang dikaikatkan dengan dengan kinerja dan grainsharing, sebagai pembagian keuntungn bagi karyawan akibat peningkatan produktivitas atau penghematan biaya. Menurut $\mathrm{H}$. Hadari Nawawi (2004:317), mengemukakan bahwa insentif adalah "Penghargaan atau ganjaran yang diberikan untuk memotivasi para karyawan agar produktivitasnya tinggi dan sifatnya tidak tetap". Pelaksanaan insentif dimaksudkan untuk meningkatkan produktifitas karyawan dan mempertahankan karyawan yang berprestasi agar tetap berada dalam perusahaan.

\section{Kinerja}

Kinerja karyawan menurut Veitzhal Riva'i (2009:548) adalah suatu fungsi dari motivasi dan kemampuan untuk menyelesaikan tugas atau pekerjaan seseorang sepatutnya memiliki derajat kesediaan dan tingkat kemampuan tertentu. Ditegaskan menurut Hanif Ismail (2009:197) menyatakan bahwa kinerja adalah pencapaian seseorang, tim atau unit kerja dalam melaksanakan tugas dibandingkan dengan sasaran yang ditargetkan kepadanya. 


\section{B. Kerangka Pemikiran}

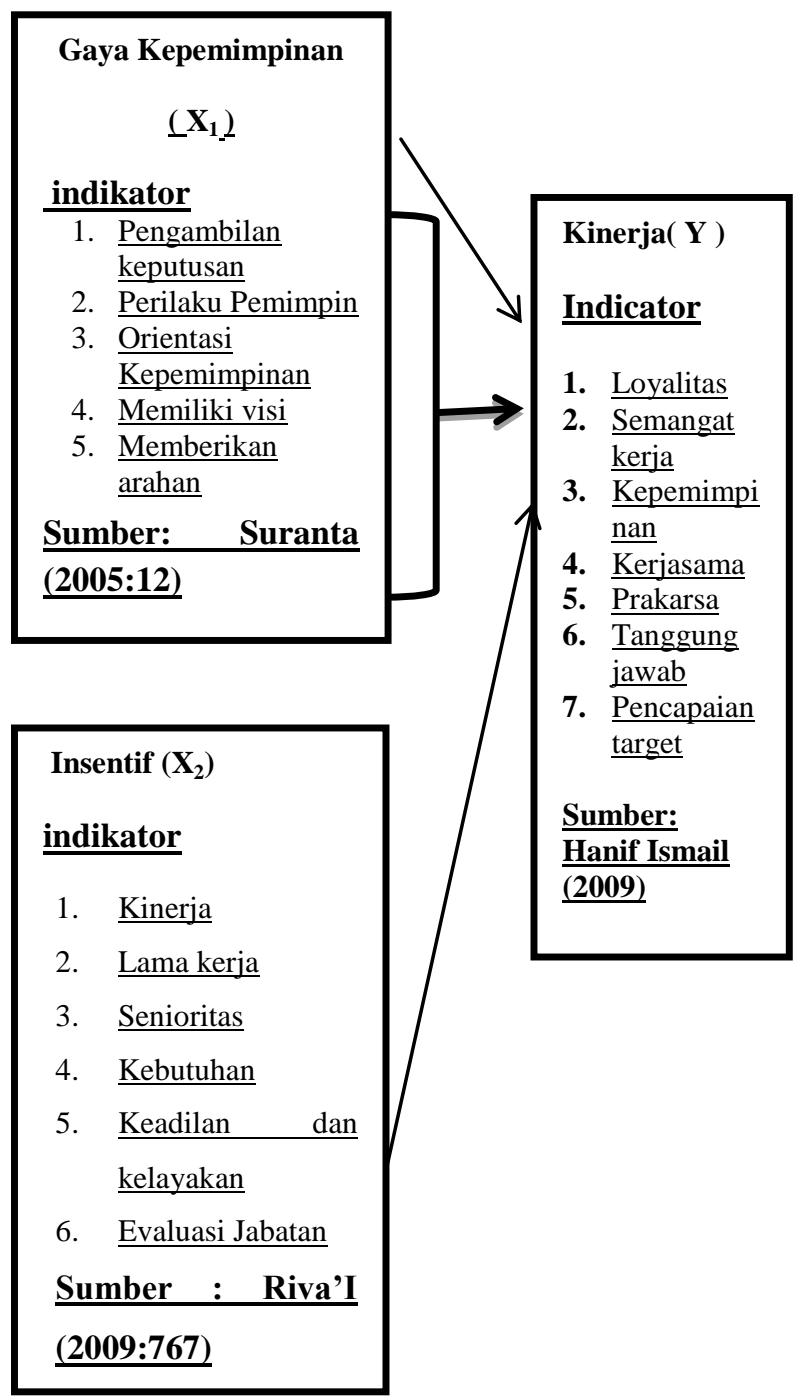

Gmbar 2.1 Kerangka Pemikiran

Sumber: Suranta (2005:12)

\section{METODOLOGI PENELITIAN}

A. Tempat dan Waktu Penelitian

Dalam Penelitian ini penulis mengambil objek penelitian di Yayasan Pendidikan Mulia Buana (YPMB), yang beralamat di Jalan Pesantren Nomor 23 Desa Kabasiran Kecamatan Parungpanjang Kabupaten Bogor Provinsi Jawa Barat. Pelaksanaan penelitian dilakukan mulai bulan September 2016 sampai dengan Januari 2017

\section{B. Metode Penelitian}

Penelitian ini dirancang dengan metode deskriptif dengan pendekatan kuantitatif. Metode kuantitatif deskriptif adalah digunakan untuk menjelaskan fenomenal yang terjadi perihal data penelitian. Sedangkan metode kuantitatif digunakan untuk menjelaskan pengaruh variabel bebas terhadap variabel terikat pada penelitian ini.

\section{Desain Penelitian}

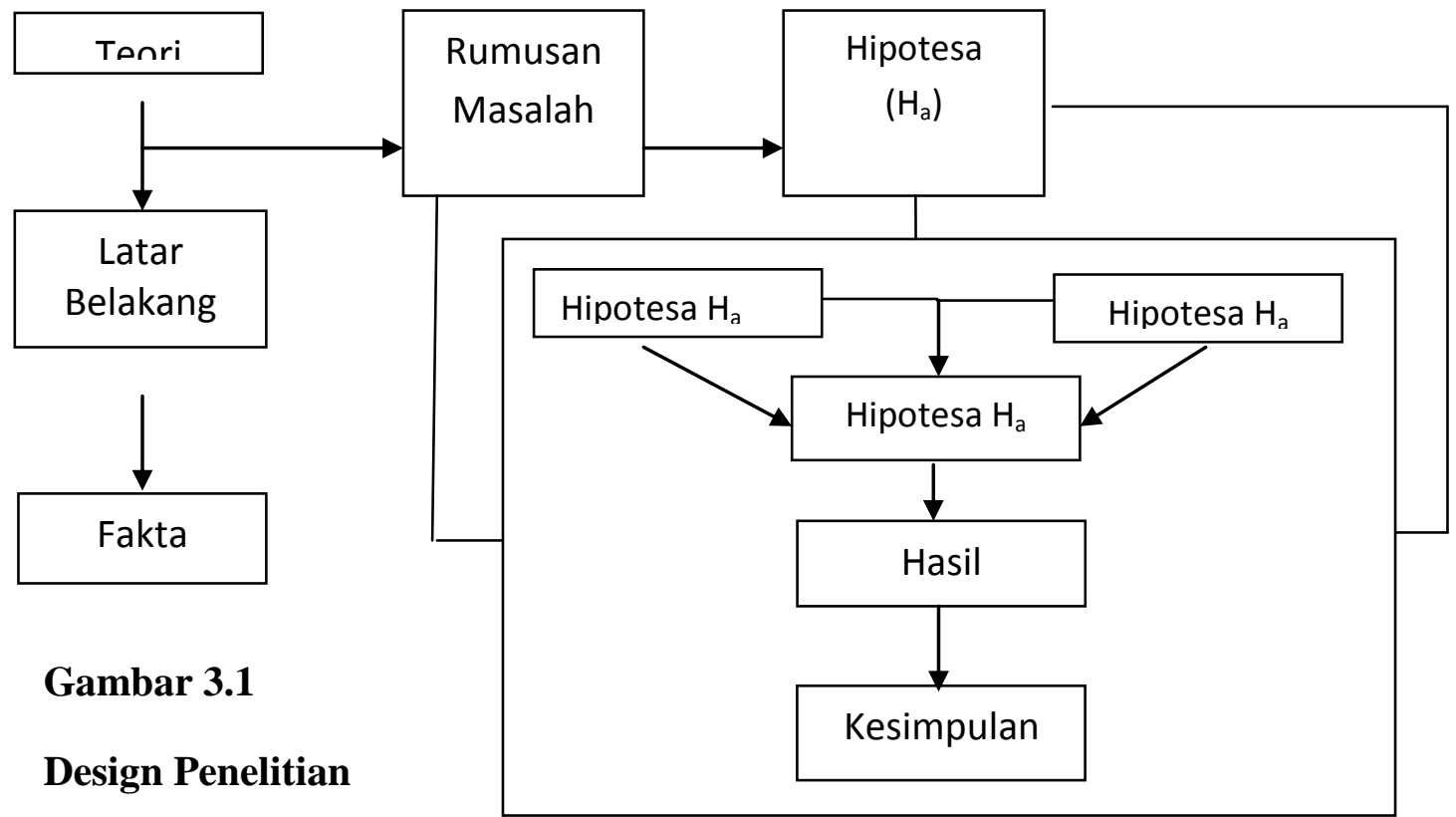




\section{Populasi \& Sampel}

1. Populasi

Menurut Sugiyono (2013:119) Populasi adalah wilayah generalisasi yang terdiri atas objek atau subjek yang mempunyai kuantitas dan karakteristik tertentu yang ditentukan oleh peneliti untuk dipelajari dan ditarik kesimpulannya. Populasi dalam penelitian ini adalah seluruh karyawan Yayasan Pendidikan Mulia Buana Parungpanjang yang berjumlah 87 karyawan.

\section{Sampel}

Menurut Sugiyono (2013:120) sampel adalah bagian dari jumlah dan karakteristik yang dimiliki oleh populasi tersebut. Penelitian ini menggunakan sampel jenuh karena objek penelitian jumlahnya terlalu sedikit atau kurang dari seratus yaitu jumlahnya 87 karyawan.

\section{E. Tekhnik Penentuan Data}

Tekhnik penentuan data dalam penelitian ini penulis membuat kuesioner sebanyak 36 pernyataan yang terdiri dari 12 pernyataan untuk variabel gaya kepemimpinan (X1), 12 pertanyaan untuk variabel insentif (X2) dan 12 pertanyaan untuk variabel kinerja (Y). Kemudian menyebarkan angket kuesioner pada karyawan Yayasan Pendidikan Mulia Buana Parungpanjang yang berjumlah 87 karyawan.

\section{F. Rancangan Analisis Data dan Uji Hipotesis}

1. Uji Kualitas Data (Instrumen) Sebelum pengujian hipotesis terlebih dahulu dilakukan pengujian persyaratan regresi yaitu :
a. Uji Validitas

Validitas adalah pengujian yang bertujuan menunjukan sejauh mana suatu alat ukur mampu mengukur apa yang ingin diukur.

Adapun rumus yang bisa digunakan untuk uji validitas dengan tekhnik korelasi product moment, yaitu:

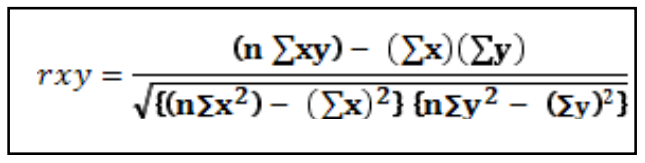

Keterangan : $\mathrm{n} \quad:$ Jumlah responden

$X$ : skor variabel (jawaban responden)

Y : Skor total dari variabel (jawaban responden)

b. Uji Reliabilitas

Uji reliabilitas adalah untuk mengetahui sejauh mana hasil pengukuran tetap konsisten, apabila dilakukan pengukuran dua kali atau lebih terhadap gejala yang sama dengan menggunakan alat pengukur yang sama pula. Uji reliabilitas alat ukur dapat dilakukan secara internal maupun eksternal. Tekhnik pengukuran reliabilitas yang digunakan pada penelitian ini adala dengan menggunakan rumus Crobach Alfa sebagai berikut :

$$
r=\frac{k}{k-1}\left(1-\frac{\Sigma S i}{S t}\right)
$$

Keterangan : $\mathrm{r}=$ Nilai Realibilitas $\mathrm{Si}=$ Varians Skor tiap item pertanyaan

$$
\begin{aligned}
& \mathrm{St}=\text { Varians total } \\
& \mathrm{K}=\text { Jumlah item }
\end{aligned}
$$
pertanyaan

2. Uji Asumsi Klasik 
Untuk memenuhi persyaratan penelitian, maka terlebih dahulu pengujian asumsi klasik dengan menggunakan uji normalitas, uji heteroskedastisitas, uji multikolinearitas dan uji korelasi.

a. Uji Normalitas

Uji normalitas bertujuan untuk menguji apakah dalam model regresi, variabel dependen dan variabel independen mempunyai distribusi normal atau tidak. Model regresi yang baik, memiliki distribusi data normal atau mendekati normal. Untuk mendeteksi normalitas dapat dilakukan dengan uji statistik.

b. Uji Heteroskedatisitas

Uji Heteroskedatisitas ini bertujuan untuk menguji apakah dalam model regresi terjadi ketidaksamaan variance dari residual satu pengamatan ke penngamatan yang lain. Jika variance dari residual satu pengamatan lain tetap, maka disebut homokedatisitas dan jika berbeda heteroskedatisitas. Model regresi yang baik adalah homokedatisitas atau tidak terjadi heteroskedatisitas

c. Uji Multikolinearitas

Uji multikolinearitas ini bertujuan untuk menguji apakah model regresi ditemukan adanya korelasi antar variabel bebas. Model regresi yang baik seharusnya tidak terjado korelasi diantara variabel bebas. Jika variabel bebas saling berkorelasi, maka variabel-variabel ini tidak orthogonal.

d. Uji Autokorelasi

Uji autokorelasi ini bertujuan untuk menguji apakah model regresi ada korelasi antara kesalahan pengganggu pada periode 1 dengan kesalahan penggganggu pada periode sebelum (t-1). Jika terjadi korelasi maka dinamakan ada problem autokorelasi

\section{Analisis Persamaan} Regresi Linier Berganda

Untuk melihat kejelasan pengaruh variabel bebas yaitu gaya kepemimpinan, insentif dengan kinerja karyawan sebagai variabel terikatnya. Penelitian ini menggunakan analisis regresi linier berganda, dengan model persamaan sebagai berikut:

$\mathrm{Y}=\mathrm{a}+\mathrm{b}_{1} \mathrm{X}_{1}+\mathrm{b}_{2} \mathrm{X}_{2}+\mathrm{e}$

Keterangan:

$\mathrm{Y}=$ nilai-nilai taksiran terikat

$\mathrm{X}_{1}=$ Nilai-nilai variabel bebas $\operatorname{pertama}\left(\mathrm{X}_{1}\right)$

$\mathrm{X}_{2}=$ nilai-nilai variable bebas kedua $\left(\mathrm{X}_{1}\right)$

$$
\begin{aligned}
\mathrm{a}= & \text { konstanta } \\
\mathrm{b}= & \text { Koefisien korelasi } \\
\mathrm{e}= & \text { variabel pengganggu } / \\
& \text { error. }
\end{aligned}
$$

\section{Pengujian Hipotesis}

Langkah langkah yang harus dilakukan untuk menganalisis hipotesis, meliputi:

a. Uji $\mathrm{t}$ (Pengujian hipotesis secara parsial) Uji $t$ atau pengujian hipotesis secara parsial adalah untuk 
mengetahui sejauh mana pengaruh secara parsial masing variabel bebas terhadap variabel terikat.

b. Uji F (Pengujian hipotesis secara simultan)

Uji $F$ atau pengujian hipotesis secara simultan adalah untuk mengetahui sejauh mana pengaruh secara bersama sama variabel bebas terhadap variabel terikat.

c. Koefisien Determinasi Perhitungan terhadap koefisien determinasi dimaksudkan untuk menganalisis seberapa besar persen kontribusi variabel bebas terhadap variabel terikat.

\section{HASIL PENELITIAN DAN PEMBAHASAN}

A. HASIL PENELITIAN

1. Uji Kualitas Data

a. Uji Valditas

Uji validitas digunakan untuk menguji sejauh mana ketepatan alat pengukur dapat mengungkapkan konsep gejala atau kejadian yang yang diukur. Item kuesioner dinyatakan valid apabila nilai $r_{\text {hitung }}$ $>\mathrm{r}$ tabel. Berikut ini tabel hasil uji validitas instrumen penelitian variabel peran kepemimpinan :

1) Ujian Validitas variabel Gaya Kepemimpinan (X1)

Berdasarkan hasil uji instrumen yang diberikan kepada 87 responden dengan jumlah butir pernyataan sebanyak 12 pernyataan yang di ajukan, semuanya dinyatakan sah/valid. Berikut ini tabel hasil uji validitas instrumen penelitian variabel

gaya

kepemimpinan :

Tabel 4.1 Hasil Uji

Validitas Gaya

Kepemimpinan

\begin{tabular}{|l|l|l|l|}
\hline $\begin{array}{l}\text { N } \\
\text { o. } \\
\text { Ite } \\
\text { m }\end{array}$ & $\begin{array}{l}\text { Nilair } \\
\text { hitung }\end{array}$ & $\begin{array}{l}\text { Nilai } \\
\mathbf{r}_{\text {tabel }}\end{array}$ & $\begin{array}{l}\text { Ketera } \\
\text { ngan }\end{array}$ \\
\hline 1 & 0.386 & 0,208 & Valid \\
\hline 2 & 0.437 & 0,208 & Valid \\
\hline 3 & 0,397 & 0,208 & Valid \\
\hline 4 & 0,427 & 0,208 & Valid \\
\hline 5 & 0,410 & 0,208 & Valid \\
\hline 6 & 0,386 & 0,208 & Valid \\
\hline 7 & 0,587 & 0,208 & Valid \\
\hline 8 & 0,477 & 0,208 & Valid \\
\hline 9 & 0,375 & 0,208 & Valid \\
\hline 10 & 0,431 & 0,208 & Valid \\
\hline 11 & 0,483 & 0,208 & Valid \\
\hline 12 & 0,483 & 0,208 & Valid \\
\hline
\end{tabular}

Sumber: Data primer diolah SPSS

2) Uji Validitas Insentif (X2)

Berdasarkan hasil uji instrumen yang diberikan kepada 87 responden dengan jumlah butir pernyataan sebanyak 12 pernyataan yang di ajukan, semuanya dinyatakan sah/valid. Berikut ini tabel hasil uji validitas instrumen penelitian variabel Insentif :

Tabel 4.2 Hasil Uji Validitas Insentif

\begin{tabular}{|l|l|l|l|}
\hline $\begin{array}{l}\mathbf{N} \\
\text { o. } \\
\text { Ite } \\
\mathbf{m}\end{array}$ & $\begin{array}{l}\text { Nilair } \\
\text { hitung }\end{array}$ & $\begin{array}{l}\text { Nilai } \\
\mathbf{r}_{\text {tabel }}\end{array}$ & $\begin{array}{l}\text { Ketera } \\
\text { ngan }\end{array}$ \\
\hline 1 & 0,387 & 0,208 & Valid \\
\hline 2 & 0,515 & 0,208 & Valid \\
\hline 3 & 0,537 & 0,208 & Valid \\
\hline 4 & 0,579 & 0,208 & Valid \\
\hline 5 & 0,421 & 0,208 & Valid \\
\hline 6 & 0,358 & 0,208 & Valid \\
\hline 7 & 0,515 & 0,208 & Valid \\
\hline 8 & 0,386 & 0,208 & Valid \\
\hline 9 & 0,538 & 0,208 & Valid \\
\hline
\end{tabular}




\begin{tabular}{|l|l|l|l|}
\hline 10 & 0,428 & 0,208 & Valid \\
\hline 11 & 0,465 & 0,208 & Valid \\
\hline 12 & 0,471 & 0,208 & Valid \\
\hline
\end{tabular}

Sumber: Data primer diolah SPSS

3) Uji Validitas Kinerja (Y)

Berdasarkan hasil uji instrumen yang diberikan kepada 87 responden dengan jumlah butir pernyataan sebanyak 12 pernyataan yang di ajukan, semuanya dinyatakan sah/valid. Berikut ini tabel hasil uji validitas instrumen penelitian variabel Kinerja :

Tabel 4.3Hasil Uji Validitas variabel Kinerja Karyawan

\begin{tabular}{|l|l|l|l|}
\hline $\begin{array}{l}\mathrm{N} \\
\text { o. } \\
\text { Ite } \\
\mathrm{m}\end{array}$ & $\begin{array}{l}\text { Nilair } \\
\text { hitung }\end{array}$ & $\begin{array}{l}\text { Nilai } \\
\mathrm{r}_{\text {tabel }}\end{array}$ & $\begin{array}{l}\text { Ketera } \\
\text { ngan }\end{array}$ \\
\hline 1 & 0,377 & 0,208 & Valid \\
\hline 2 & 0,499 & 0,208 & Valid \\
\hline 3 & 0,546 & 0,208 & Valid \\
\hline 4 & 0,458 & 0,208 & Valid \\
\hline 5 & 0,441 & 0,208 & Valid \\
\hline 6 & 0,464 & 0,208 & Valid \\
\hline 7 & 0,413 & 0,208 & Valid \\
\hline 8 & 0,433 & 0,208 & Valid \\
\hline 9 & 0,539 & 0,208 & Valid \\
\hline 10 & 0,430 & 0,208 & Valid \\
\hline 11 & 0,445 & 0,208 & Valid \\
\hline 12 & 0,469 & 0,208 & Valid \\
\hline
\end{tabular}

Sumber: Data primer diolah SPSS

b. Uji Reliabilitas

Uji reliabilitas digunakan untuk menguji sejauh mana keandalan suatu alat pengukur untuk dapat digunakan lagi untuk penelitian yang sama. Berikut ini disajikan hasil dari uji reliabilitas instrumen penelitian :

1) Uji Reliabilitas Variabel $X 1$, $\mathrm{X} 2$ dan $\mathrm{Y}$

Untuk menguji reliabilitas variabel gaya kepemimpinan, Insentif dan kinerja karyawan. Peneliti menggunakan rumus
Alpha Cronchbach di program SPSS versi 21. Hasil uji reliabilitas variabel gaya kepemimpinan (X1), Insentif (X2) dan gaya kepemimian (Y) dapat dilihat pada tabel berikut:

Tabel 4.4 : Hasil Uji Reliabilitas Variabel X1, X2 dan variabel $Y$

\begin{tabular}{|l|l|l|}
\hline Variabel & $\begin{array}{l}\text { Nilai } \\
\text { Alpha } \\
\text { Cronb } \\
\text { ach }\end{array}$ & $\begin{array}{l}\text { Keteran } \\
\text { gan }\end{array}$ \\
\hline $\begin{array}{l}\text { Gaya } \\
\text { Kepemimpin } \\
\text { an }\end{array}$ & 0,613 & Reliabel \\
\hline Insentif & 0,666 & Reliabel \\
\hline $\begin{array}{l}\text { KinerjaKary } \\
\text { awan }\end{array}$ & 0,650 & Reliabel \\
\hline
\end{tabular}

Sumber: Data primer diolah SPSS

2. Uji Normalitas Data

Uji normalitas bertujuan untuk menguji apakah dalam model regresi baik variabel independen maupun variabel dependen memiliki distribusi normal atau tidak. Model regresi yang baik adalah yang memiliki distribusi data normal atau mendekati normal. Uji normalitas menggunakan uji kolmogrovsmirnov dengan kriterianya jika hasil uji perhitungan lebih besar dari 0,05 berarti data berdistribusi normal.

Tabel 4.5 Hasil Uji

Kolmograv-smirnov dengan SPSS

One-Sample Kolmogorov-Smirnov

Test

\begin{tabular}{|c|c|c|}
\hline & & $\begin{array}{l}\text { Standardized } \\
\text { Residual }\end{array}$ \\
\hline $\mathrm{N}$ & & 87 \\
\hline & Mean & .0000000 \\
\hline Parameters ${ }^{\mathrm{a}, \mathrm{b}}$ & Std. & .98830369 \\
\hline Most & Absolute & .116 \\
\hline Extreme & Positive & .100 \\
\hline Differences & Negative & -.116 \\
\hline
\end{tabular}


\begin{tabular}{|l|l|} 
Kolmogorov-Smirnov & 1.081 \\
$\mathrm{Z}$ & \\
Asymp. Sig. (2-tailed) & .193 \\
\hline
\end{tabular}

a. Test distribution is Normal.

b. Calculated from data.

Dari hasil perhitungan uji kolmogrov-smirnov dengan bantuan software SPSS dapat dilihat bahwa nilai signifikansi yang didapat adalah $0,193>0,05$ sehingga dapat dikatakan tidak signifikan dan berarti data yang diuji normal.

b. Uji Multikolinearitas

Uji multikolinearitas bertujuan untuk menguji apakah model regresi ditemukan adanya korelasi antar variabel. Berdasarkan ketentuan, jika variabel-variabel bebas memiliki tolerance > 0,1 (10\%) dan memiliki nilai Variance Inflation Factor < 10, maka model regresi tersebut bebas dari masalah multikolinearitas. Hasil SPSS dari uji multikolinearitas ini dapat dilihat pada tabel 4.10, sebagai berikut:

\section{Tabel 4.6 Hasil Uji Multikolinearitas}

\section{Coefficients $^{\mathrm{a}}$}

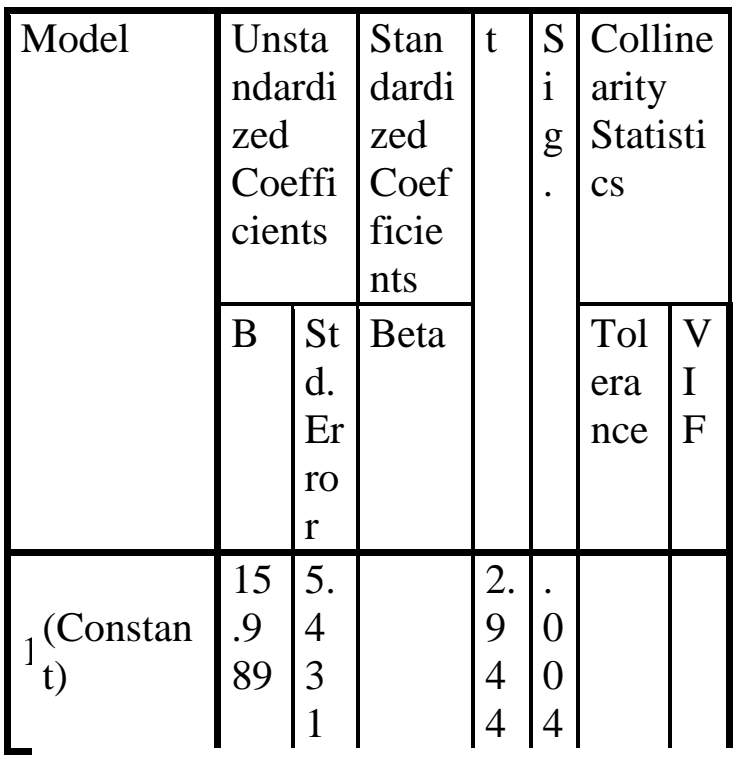

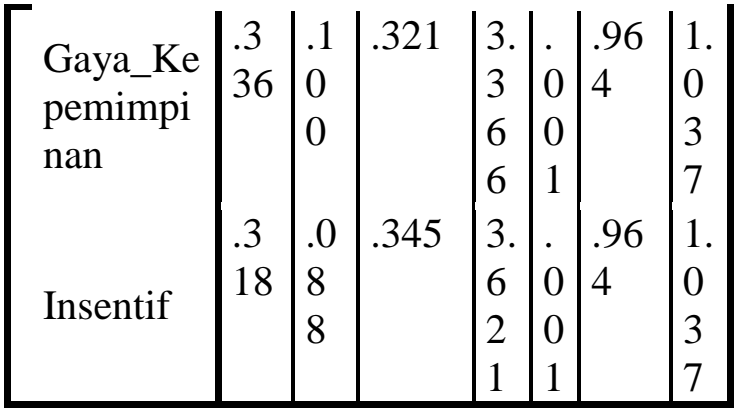

a. Dependent Variable:

Kinerja_Karyawan

Berdasarkan hasil tersebut maka dapat disimpulkan bahwa model penelitian ini bebas dari multikolinearitas. Dengan demikian model persamaan regresi tidak terdapat masalah multikolinearitas atau dapat dikatakan bebas dari multikolinearitas.

c. Uji Heteroskedastisitas

Uji Heteroskedatisitas ini bertujuan untuk menguji apakah dalam model regresi terjadi ketidaksamaan variance dari residual satu pengamatan ke pengamatan yang lain. Jika variance dari residual satu pengamatan lain tetap, maka disebut homokedatisitas dan jika berbeda heteroskedatisitas. Model regresi yang baik adalah homokedastisitas atau tidak terjadi heteroskedastisitas.

Tabel 4.7 Hasil Uji heteroskedatisitas

Coefficients $^{\mathbf{a}}$
\begin{tabular}{|l|l|l|l|l|l|}
\hline Model & $\begin{array}{l}\text { Unstand } \\
\text { ardized } \\
\text { Coeffici } \\
\text { ents }\end{array}$ & $\begin{array}{l}\text { Standa } \\
\text { rdized } \\
\text { Coeffi } \\
\text { cients }\end{array}$ & t & $\begin{array}{l}\text { Si } \\
\text { g. }\end{array}$ \\
\cline { 2 - 5 } & B & $\begin{array}{l}\text { Std } \\
\text { Beta } \\
\text { Err } \\
\text { or }\end{array}$ & & & \\
\hline 1 (Constant) & 02 & $\begin{array}{l}3.8 \\
12\end{array}$ & & .6 & .5 \\
56 & 1 \\
3
\end{tabular}




\begin{tabular}{l|l|l|l|l|l|} 
Gaya_Kepe & .10 & .07 & .155 & 1. & .1 \\
mimpinan & 0 & 0 & & 42 & 5 \\
& - & .06 & -.163 & 7 & 7 \\
& -09 & 2 & & 1.1 \\
Insentif & 3 & & & 50 & 7 \\
& & & & 1 & \\
\hline
\end{tabular}

a. Dependent Variable: ABSRESID

Dari tabel diatas, dapat dilihat bahwa signifikansi hasil korelasi lebih besar dari 0,05 (5\%) maka persamaan regresi tersebut tidak mengandung heteroskedatisitas atau homokedatisitas, sehingga dapat disimpulkan bahwa pada model ini tidak terjadi masalah heteroskedatisitas.

\section{d) Uji Autokorelasi}

Uji autokorelasi ini bertujuan untuk menguji apakah model regresi ada korelasi antara kesalahan pengganggu pada periode 1 dengan kesalahan penggganggu pada periode sebelum $(\mathrm{t}$ 1). Jika terjadi korelasi maka dinamakan ada problem autokorelasi. Untuk melihat ada tidaknya autokorelasi dapat diuji dengan menggunakan uji Durbin Watson dengan hasil sebagai berikut:

Tabel $\mathbf{4 . 8}$ Hasil Uji Autokorelasi
Model Summary
\begin{tabular}{|l|l|l|l|l|l|}
\hline $\begin{array}{l}\text { Mod } \\
\text { el }\end{array}$ & R & $\begin{array}{l}\text { R } \\
\text { Squa } \\
\text { re }\end{array}$ & $\begin{array}{l}\text { Adjust } \\
\text { ed R R } \\
\text { Square }\end{array}$ & $\begin{array}{l}\text { Std. } \\
\text { Error } \\
\text { of the } \\
\text { Estim } \\
\text { ate }\end{array}$ & $\begin{array}{l}\text { Durbi } \\
\text { n- } \\
\text { Wats } \\
\text { on }\end{array}$ \\
\hline 1 & .51 & .264 & .247 & 4.258 & 1.585 \\
$4^{\text {a }}$ & & (Constant), Insentif, \\
a. Predictors: (Caniable: \\
Gaya_Kepemimpinan \\
b. Dependent \\
Kinerja_Karyawan
\end{tabular}

Dari hasil pengujian diatas tampak bahwa nilai Durbin Watson (DW) menunjukkan nilai sebesar 1,585 yang berarti lebih kecil dari 2, maka dapat disimpulkan bahwa tidak terjadi autokorelasi yang artinya tidak ada korelasi yang terjadi antara residual pada suatu pengamatan dengan pengamatan lain dalam model regresi.

3. Analisis Persamaan Regresi Linier Berganda

Pengaruh secara simultan dalam penelitian ini dilakukan dengan membaca tabel dibawah ini untuk mengetahui nilai determinasi yang dipergunakan untuk mengetahui besarnya pengaruh secara simultan. Berdasarkan estimasi regresi berganda dengan SPSS versi 21, diperoleh hasil seperti tabel berikut :

Tabel 4.9 Hasil Perhitungan

Analisa Regresi Berganda

Coefficients $^{\mathrm{a}}$

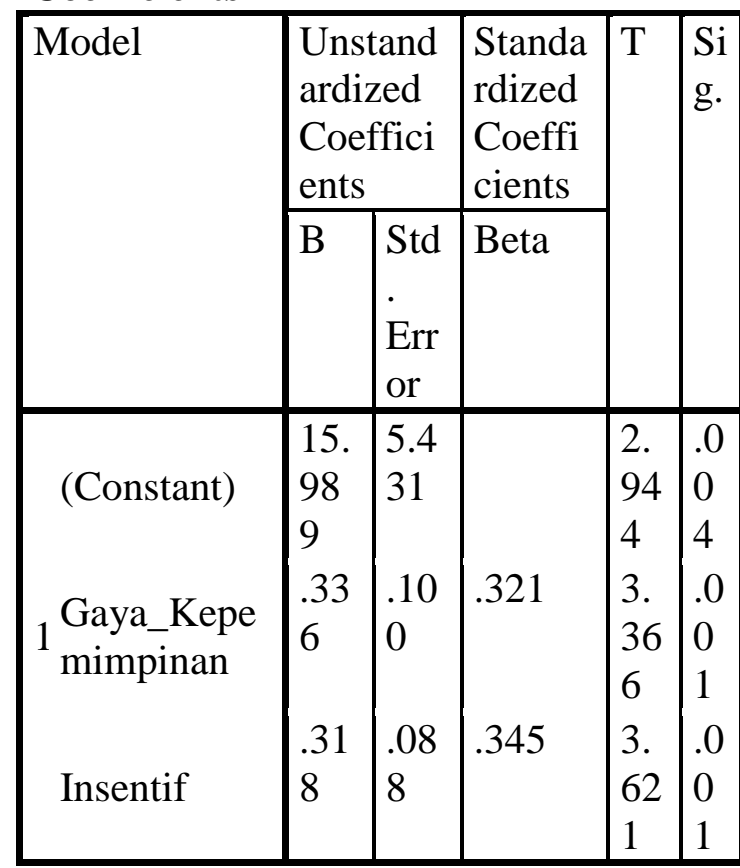

a. Dependent

Variable:

Kinerja_Karyawan

Dari tabel coefficients diatas diperoleh model regresi linier berganda sesuai persamaan berikut ini:

$Y=15,989+0,336 X_{1}+0,318 X_{2}$

\section{Pengujian Hipotesis}

a. Uji F (Uji Hipotesis secara simultan) 
Untuk menguji pengaruh variabel bebas secara bersama-sama di uji dengan menggunakan uji F. Hasil perhitungan regresi secara simultan diperoleh sebagai berikut:

Tabel 4.10 Hasil Perhitungan Uji F

ANOVA

\begin{tabular}{|l|l|l|l|l|l|}
\hline Model & $\begin{array}{l}\text { Sum } \\
\text { of } \\
\text { Square } \\
\text { s }\end{array}$ & $\begin{array}{l}\text { D } \\
\text { f }\end{array}$ & $\begin{array}{l}\text { Mean } \\
\text { Squar } \\
\text { e }\end{array}$ & F & $\begin{array}{l}\text { Sig } \\
.\end{array}$ \\
\hline $\begin{array}{l}\text { Regress } \\
\text { ion }\end{array}$ & 546.58 & 2 & 273.2 & 15.0 & .00 \\
Residua & 1523.1 & 8 & 18.13 & 72 & $0^{\mathrm{b}}$ \\
1 & 59 & 4 & 3 & & \\
1 & 2069.7 & 8 & & & \\
Total & 47 & 6 & & & \\
\hline
\end{tabular}

a.

Dependent

Variable:

Kinerja_Karyawan

b. Predictors: (Constant), Insentif, Gaya_Kepemimpinan

Besar pengaruh secara simultan 0,264 , hal ini menggambarkan bahwa pengaruh secara bersama-sama variabel bebas terhadap terikat sebesar $26,4 \%$, sedangkan pengaruh diluar model ini diketahui sebesar $73,6 \%$. Adapun nilai $\mathrm{F}$ hitung dari tabel diatas diketahui sebesar 15,072.

\section{b. Koefisien determinasi}

Koefisien determinasi merupakan besaran yang menunjukan besarnya variasi variabel dependen yang dapat dijelaskan oleh variabel independennya. Dengan kata lain koefisien determinasi ini diguakan untuk mengukur seberapa variabelvariabel bebas dalam menerangkan variabel terikatnya. Nilai koefisien determinasi dapat dilihat sebagai berikut :
Tabel 4.11 Hasil Perhitungan Uji Koefisien Determinasi Model Summary

\begin{tabular}{|l|l|l|l|l|}
\hline $\begin{array}{l}\text { Mode } \\
1\end{array}$ & $\mathrm{R}$ & $\begin{array}{l}\text { R } \\
\text { Squar } \\
\mathrm{e}\end{array}$ & $\begin{array}{l}\text { Adjuste } \\
\mathrm{d} \quad \mathrm{R} \\
\text { Square }\end{array}$ & $\begin{array}{l}\text { Std. } \\
\text { Error of } \\
\text { the } \\
\text { Estimat } \\
\mathrm{e}\end{array}$ \\
\hline 1 & $\begin{array}{l}.514 \\
\mathrm{a}\end{array}$ & .264 & .247 & 4.258 \\
\hline
\end{tabular}

Predictors: (Constant), Insentif, Gaya_Kepemimpinan

Hasil perhitungan diketahui bahwa koefisien determinasi (Adjusted R Square) yang diperoleh sebesar $24,7 \%$. Hal ini berarti $24,7 \%$ variasi variabel kinerja dapat dijelaskan oleh variabel kepemipinan dan isnsentif sedangkan sisanya dipengaruhi oleh variabel lain yang tidak diteliti dalam penelitian ini.

c. Uji t (Uji hipotesis secara parsial)

Untuk menentukan $\mathrm{t}$ tabel, yaitu dapat dari membaca tabel distribusi-t untuk taraf signifansi dan dk $=\mathrm{n}-\mathrm{k}-1$, dalam hal ini $\mathrm{n}=$ banyaknya pasang data, $\mathrm{k}=$ banyaknya variabel bebas.

$\mathrm{Dk}=87-2-1$

$\mathrm{Dk}=84$

1) Uji t variabel $x 1$ terhadap y (Gaya Kepemimpinan terhadap kinerja)

Hasil uji t pada variabel $x 1$ terhadap $Y$ yaitu gaya kepemimpinan terhadap kinerja karyawan dapat ditampilkan , pada tabel berikut :

Tabel 4.12 Model Regresi Gaya Kepemimpinan terhadap Kinerja Karyawan

Coefficients $^{\mathrm{a}}$

\begin{tabular}{|l|l|l|l|l|}
\hline Model & $\begin{array}{l}\text { Unstand } \\
\text { ardized } \\
\text { Coeffici } \\
\text { ents }\end{array}$ & $\begin{array}{l}\text { Standa } \\
\text { rdized } \\
\text { Coeffi } \\
\text { cients }\end{array}$ & T & $\begin{array}{l}\text { Si } \\
\text { g. }\end{array}$ \\
\hline
\end{tabular}




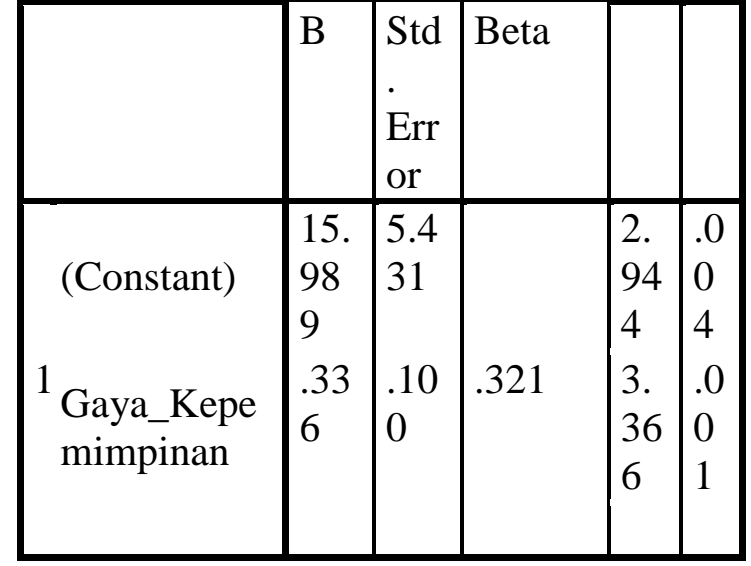

a. Dependent

Variable:

Kinerja_Karyawan

Berdasarkan hasil uji hipotesis diatas, diperoleh $t_{\text {hitung }}$ sebesar $3,366>t$ tabel 1,667. Dan memiliki nilai signifikansi $0,001<0,05$ sehingga $\mathrm{H}_{0}$ ditolak dan $\mathrm{H}_{\mathrm{a}}$ diterima. Hal ini berarti $\mathrm{X}_{1}$ terhadap $\mathrm{Y}$ bersifat positif dan berpengaruh signifikan variabel gaya kepemimpinan terhadap kinerja karyawan.

Diketahui bahwa variabel gaya kepemimpinan $\left(\mathrm{X}_{1}\right)$ mempunyai pengaruh positif dan signifikan sebesar 0,336 atau 33,6\% terhadap kinerja karyawan pada Yayasan Pendidikan Mulia Buana Parungpanjang, yang artinya semakin baik gaya kepemimpinan pada yayasan maka akan semakin baik kinerja karyawan pada Yayasan Pendidikan Mulia Buana Parungpanjang.

2) Uji t variabel $x 2$ terhadap $y$ (Insentif terhadap kinerja)

Hasil uji $\mathrm{t}$ pada variabel $\mathrm{x} 2$ terhadap $\mathrm{Y}$ yaitu insentif terhadap kinerja karyawan dapat ditampilkan , pada tabel berikut :

\section{Tabel 4.13 Model Regresi Insentif terhadap Kinerja Karyawan}

\section{Coefficients $^{\mathrm{a}}$}

\begin{tabular}{|l|l|l|l|l|}
\hline Model & $\begin{array}{l}\text { Unstandar } \\
\text { dized } \\
\text { Coefficien } \\
\text { ts }\end{array}$ & $\begin{array}{l}\text { Standard } \\
\text { ized } \\
\text { Coeffici } \\
\text { ents }\end{array}$ & $\mathrm{T}$ & $\begin{array}{l}\text { Si } \\
\text { g. }\end{array}$ \\
\hline
\end{tabular}

\begin{tabular}{|c|c|c|c|c|c|}
\hline & B & \begin{tabular}{|l} 
Std. \\
Erro \\
$\mathrm{r}$ \\
\end{tabular} & Beta & & \\
\hline $\begin{array}{l}\text { (Const } \\
\text { ant) }\end{array}$ & \begin{tabular}{|l|}
15.9 \\
89 \\
\end{tabular} & \begin{tabular}{|l|}
5.43 \\
1 \\
\end{tabular} & & \begin{tabular}{|l|}
2.9 \\
44 \\
\end{tabular} & \begin{tabular}{|l|}
.0 \\
04 \\
\end{tabular} \\
\hline $\begin{array}{l}1 \text { Insenti } \\
\mathrm{f}\end{array}$ & .318 & .088 & .345 & $\begin{array}{l}3.6 \\
21\end{array}$ & $\begin{array}{l}.0 \\
01\end{array}$ \\
\hline
\end{tabular}

a. Dependent

Variable:

Kinerja_Karyawan

Berdasarkan hasil uji hipotesis diatas $X_{2}$ terhadap $\mathrm{Y}$, diperoleh $\mathrm{t}_{\text {hitung }}$ sebesar 3,621 $>\mathrm{t}$ tabel 1,667. Dan memiliki nilai signifikansi $0,001<0,05$ sehingga $\mathrm{H}_{0}$ ditolak dan $\mathrm{H}_{\mathrm{a}}$ diterima. $\mathrm{H}_{0}$ ditolak dan $\mathrm{H}_{\mathrm{a}}$ diterima karena nilai $\mathrm{t}$ hitung $>\mathrm{t}$ tabel. Nilai signifikansi $0,001<0,05$ dari taraf kepercayaan yang telah ditetapkan. Hal ini berarti $\mathrm{X}_{2}$ terhadap $\mathrm{Y}$ bersifat positif dan berpengaruh signifikan.

Kesimpulan dari persamaan regresi diatas dapat dinyatakan bahwa Insentif $\left(\mathrm{X}_{2}\right)$ terhadap Kinerja Karyawan (Y) berpengaruh positif dengan nilai koefisien regresi parsial sebesar 0,318 atau 31,8\%, yang artinya semakin baik pemberian insentif pada yayasan maka akan semakin baik kinerja karyawan pada Yayasan Pendidikan Mulia Buana Parungpanjang.

\section{B. Pembahasan Penelitian}

Setelah diketahui hasil temuan dalam penelitian ini, selanjutnya di analisis untuk melihat seberapa baik data tersebut mempresentasikan penelitian yang diangkat, terutama kemampuan dalam menjelaskan pengaruh gaya kepemimpinan dan insentif terhadap kinerja karyawan. Selanjutnya akan dilakukan pembahasan secara deskriftif, pembahasan uji parsial dan pembahasan uji simultan terkait hasil temuan-temuan dalam penelitian ini.

\section{Pembahasan Deskriftif}

Secara keseluruhan gaya kepemimpinan yang dimiliki Yayasan Pendidikan Mulia Buana Parungpanjang dianggap cukup baik oleh responden 
terutama dari pengambilan keputusan. Variabel gaya kepemimpinan berpengaruh signifikan terhadap kinerja karyawan artinya semakin baik gaya kepemimpinan dimata karyawan maka akan semakin baik kinerja karyawan pada Yayasan Pendidikan Mulia Buana Parungpanjang.

Untuk variabel insentif yang ada Yayasan Pendidikan Mulia Buana Parungpanjang dianggap cukup baik oleh responden terutama dari segi pemerhatian pada sisi kebutuhan di Artinya semakin baik insentif yang diberikan Yayasan Pendidikan Mulia Buana Parungpanjang maka akan semakin baik kinerja karyawan pada Yayasan Pendidikan Mulia Buana Parungpanjang.

Dari hasil uji hipotesis berdasarkan uji koefisien determinasi dapat disimpulkan bahwa variabel gaya kepemimpinan dan insentif secara simultan mempunyai pengaruh yang cukup signifikan terhadap kinerja karyawan dengan nilai sebesar $26,4 \%$.

\section{Pembahasan Uji Parsial (Uji t)}

Berdasarkan hasil uji hipotesis diatas, diperoleh $t_{\text {hitung }}$ sebesar $3,366>\mathrm{t}$ tabel 1,667. Dan memiliki nilai signifikansi $0,001<0,05$ sehingga $\mathrm{H}_{0}$ ditolak dan $\mathrm{H}_{\mathrm{a}}$ diterima. Hal ini berarti $\mathrm{X}_{1}$ terhadap $\mathrm{Y}$ bersifat positif dan berpengaruh signifikan variabel gaya kepemimpinan terhadap kinerja karyawan. Diketahui bahwa variabel gaya kepemimpinan $\left(\mathrm{X}_{1}\right)$ mempunyai pengaruh positif dan signifikan sebesar 0,336 atau $33,6 \%$ terhadap kinerja karyawan pada Yayasan Pendidikan Mulia Buana Parungpanjang, yang artinya semakin baik gaya kepemimpinan pada yayasan maka akan semakin baik kinerja karyawan pada Yayasan Pendidikan Mulia Buana Parungpanjang.

Hasil ini sesuai dengan penelitian yang dilakukan, Pada kuisioner yang telah diberikan kepada Responden paling banyak menjawab setuju pada butir nomor 2 sebanyak 37 responden dari 87 responden atau $42,53 \%$, butir ini berindikator pengambilan keputusan. Pengambilan keputusan dan kebijakan yang dilakukan pimpinan pada dasarnya untuk kepentingan lembaga dan karyawan. Artinya pengambilan keputusan pada gaya kepemimpinan di yayasan sudah berjalan dengan baik. Untuk variabel gaya kepemimpinan masih cukup banyak responden menjawab kurang setuju 6 responden (7\%) dan cukup setuju 38 responden $(43,7 \%)$ dari butir instrument nomor 4 yaitu indikator perilaku pemimpin, Sikap pemimpin sebaiknya harus mampu memotivasi karyawan bekerja lebih baik lagi. Jadi pihak yayasan atau sekolah harus mampu meningkatkan gaya kepemimpinan di lingkungan sekolah diantaranya memperbaiki perilaku pemimpin lebih baik lagi.

Berdasarkan hasil uji hipotesis diatas $\mathrm{X}_{2}$ terhadap $\mathrm{Y}$, diperoleh $\mathrm{t}_{\text {hitung }}$ sebesar 3,621 > $\mathrm{t}$ tabel 1,667. Dan memiliki nilai signifikansi $0,001<0,05$ sehingga $\mathrm{H}_{0}$ ditolak dan $\mathrm{H}_{\mathrm{a}}$ diterima. $\mathrm{H}_{0}$ ditolak dan $\mathrm{H}_{\mathrm{a}}$ diterima karena nilai $\mathrm{t}_{\text {hitung }}$ $>\mathrm{t}_{\text {tabel. }}$. Nilai signifikansi $0,001<0,05$ dari taraf kepercayaan yang telah ditetapkan. Hal ini berarti $\mathrm{X}_{2}$ terhadap $\mathrm{Y}$ bersifat positif dan berpengaruh signifikan. Kesimpulan dari persamaan regresi diatas dapat dinyatakan bahwa Insentif $\left(\mathrm{X}_{2}\right)$ terhadap Kinerja Karyawan (Y) berpengaruh positif dengan nilai koefisien regresi parsial sebesar 0,318 atau $31,8 \%$, yang artinya semakin baik pemberian insentif pada yayasan maka akan semakin baik kinerja karyawan pada Yayasan Pendidikan Mulia Buana Parungpanjang.

Hasil ini sesuai dengan penelitian yang dilakukan, Pada kuisioner yang telah diberikan kepada responden. Responden paling banyak menjawab sangat setuju pada butir nomor 7 sebanyak 33 responden dari 87 responden atau $37,93 \%$, butir ini berindikator kebutuhan, Adanya insentif mampu membantu memenuhi kebutuhan 
sehari-hari diluar gaji pokok, artinya pemberian insentif sangat memperhatikan kebutuhan karyawan. Untuk variabel insentif masih cukup banyak responden menjawab kurang setuju 12 responden $(13,8 \%)$ dan cukup setuju 37 responden $(42,5 \%)$ dari butir instrumen nomor 3 yaitu indikator kinerja. Pemberian insentif sebaiknya nominal atau besarannya berdasarkan kinerja karyawan. Jadi pihak yayasan atau sekolah harus mampu memperhatikan dan meningkatkan pemberian insentif dilingkungan sekolah diantaranya dengan memperhatikan kinerja agar tidak terjadi kecemburuan antar pegawai.

\section{Pembahasan Uji Simultan (Uji F)}

Berdasarkan hasil uji hipotesis pengujian secara simultan variabel bebas atau Uji $\mathrm{F}$ hasilnya $\mathrm{H}_{0}$ ditolak dan $\mathrm{H}_{\mathrm{a}}$ diterima karena nilai $F_{\text {hitung }}>F_{\text {tabel, yaitu }}$ $F_{\text {hitung }}(15,072)>F_{\text {tabel }}(3,11)$ dan nilai signifikansi $0,001<0,05$ dari taraf kepercayaan yang telah ditetapkan. Nilai $\mathrm{R}^{2} \quad 0,264$ atau $26,4 \%$. Hal ini berarti terdapat pengaruh secara bersama-sama variabel $\mathrm{X}_{1}$ dan $\mathrm{X}_{2}$ terhadap variabel $\mathrm{Y}$ sebesar $26,4 \%$ yang bersifat positif dan berpengaruh signifikan.

Hasil ini sesuai dengan penelitian yang telah dilakukan bahwa secara bersama-sama gaya kepemimpinan dan insentif berpengaruh signifikan dan positif terhadap kinerja karyawan Yayasan Pendidikan Mulia Buana Parungpanjang Bogor. Semakin baik gaya kepemipinan dan insentif secara bersama-sama maka akan semakin baik pula kinerja karyawan Yayasan Pendidikan Mulia Buana Parungpanjang Bogor.

\section{KESIMPULAN}

Berdasarkan hasil penelitian, maka disimpulkan, sebagai berikut :

Ismail, Hanif. Balance scorecard. Penerbit: PT Gramedia
1. Gaya Kepemimpinan berpengaruh positif dan signifikan terhadap kinerja karyawan Yayasan Pendidikan Mulia Buana Parungpanjang, Bogor sebesar $33,6 \%$.

2. Insentif berpengaruh positif dan signifikan terhadap kinerja karyawan Yayasan Pendidikan Mulia Buana Parungpanjang, Bogor sebesar $31,8 \%$.

3. Gaya Kepemimpinan dan Insentif secara simultan berpengaruh positif dan signifikan terhadap kinerja karyawan Yayasan Pendidikan Mulia Buana Parungpanjang, Bogor sebesar 26,4\%. Selebihnya dipengaruhi oleh variabel atau faktor lain diluar penelitian ini.

\section{DAFTAR PUSTAKA}

Chatab, Nevizond. Diagnostic Management, cetakan kesatu. Penerbit: PT Serambi Ilmu Semesta, Jakarta, 2007.

Feryanto, Agung, Dkk. Materi Ekonomi Volume 3 "Spesialisasi dan Pembagian kerja". Penerbit: Cempaka Putih, Klaten, 2013.

Guritno, Bambang Manajemen Personalia. PT Gramedia Pustaka Utama, Jakarta, 2006.

Handoko, Hani T. Manajemen, edisi kedua. Penerbit: BPFE, Yogyakarta, 2008.

Hasibuan, Malayu. Manajemen Sumberdaya Manusia. Penerbit: PT Bumi Aksara, Jakarta, 2007. 
Pustaka Utama, Jakarta, 2009

Riva'i, Veitzhal. Manajemen

Sumberdaya Manusia

untuk Perusahaan.

Penerbit: PT Ragrafindo

Persada, Jakarta, 2009.

Simamora, Hendri. Pengembangan

Manajemen Sumber Daya

Manusia. Salemba empat,

Jakarta, 2004.

Sugiyono, Metode Penelitian

Kuantitatif Kualitatif

$R \& D$. Penerbit: CV Alfa

Beta, Bandung, 2011.

Suranta, Manajemen Sumber Daya Manusia. Penerbit: CV

Alfa Beta, Bandung, 2005

Zakiyudin, Ais. Sistem Informasi Manajemen. Penerbit: PT. Mitra Wacana Media, Jakarta, 2011. 